\title{
Elevated Levels of 1,25-Dihydroxyvitamin D in Plasma as a Missing Risk Factor for Celiac Disease
}

This article was published in the following Dove Press journal:

Clinical and Experimental Gastroenterology

\author{
Seth Scott Bittker (D) \\ Ronin Institute, Montclair, NJ, USA
}

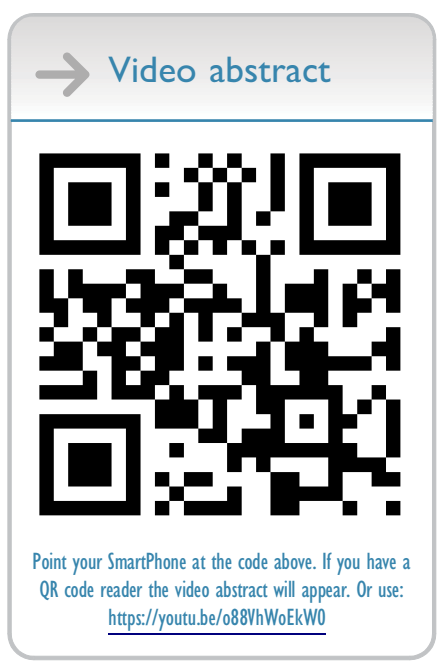

Correspondence: Seth Scott Bittker 17 Edmond Street, Darien, CT 06820, USA

Tel + I 212-203-6550

Email sbittker@yahoo.com

\begin{abstract}
The prevalence of celiac disease (CD) has increased significantly in some developed countries in recent decades. Potential risk factors that have been considered in the literature do not appear to provide a convincing explanation for this increase. This has led some researchers to hypothesize that there is a "missing environmental factor" that increases the risk of $\mathrm{CD}$. Based on evidence from the literature, the author proposes that elevation in plasma levels of 1,25-dihydroxyvitamin $\mathrm{D}\left[1,25(\mathrm{OH})_{2} \mathrm{D}\right]$ is a missing risk factor for $\mathrm{CD}$, and relatedly that significant oral vitamin $\mathrm{D}$ exposure is a "missing environmental factor" for $\mathrm{CD}$. First, elevated plasma levels of $1,25(\mathrm{OH})_{2} \mathrm{D}$ are common in $\mathrm{CD}$, especially in the newly diagnosed. Second, nine distinct conditions that increase plasma levels of $1,25(\mathrm{OH})_{2} \mathrm{D}$ are either associated with $\mathrm{CD}$ or have indications of such an association in the literature. Third, a retrospective study shows that sustained oral vitamin D supplementation in infancy is associated with increased CD risk, and other studies on comorbid conditions support this association. Fourth, large doses of oral vitamin D upregulate many of the same cytokines, chemokines, and toll-like receptors that are upregulated in CD. Fifth, epidemiological evidence, such as the timing of the inception of a CD "epidemic" in Sweden, the increased prevalence of $\mathrm{CD}$ in Finland and the United States in recent decades, the unusually low prevalence of $\mathrm{CD}$ in Germany, and the differential in prevalence between Finnish Karelians and Russian Karelians, may all be explained by oral vitamin D exposure increasing CD risk. The same is true of some seemingly contradictory results in the literature on the effects of breastfeeding on CD risk. If future research validates this hypothesis, adjustments to oral vitamin $\mathrm{D}$ consumption among those who have genetic susceptibility may decrease the risk of $\mathrm{CD}$ in these individuals.
\end{abstract}

Keywords: vitamin D, vitamin D3, coeliac, gluten, epidemiology, calcitriol

\section{Plain Language Summary}

Prevalence of $\mathrm{CD}$ has increased significantly in some countries in recent decades. Existing explanations that have been postulated for this increase in prevalence are inadequate. Based on evidence from the medical literature, the author proposes that high levels of $1,25(\mathrm{OH})_{2} \mathrm{D}$ in blood plasma increase the risk of $\mathrm{CD}$. In addition, as consumption of oral vitamin $\mathrm{D}$ increases the levels of $1,25(\mathrm{OH})_{2} \mathrm{D}$ in blood plasma, significant vitamin $\mathrm{D}$ supplementation or fortification will increase the risk of $\mathrm{CD}$. This hypothesis is supported by data from the literature on $\mathrm{CD}$ comorbidity, gastrointestinal and immunological effects of vitamin D consumption, and CD epidemiology.

\section{Introduction}

Celiac disease (CD) is a chronic small intestine enteropathy induced by exposure to gluten. ${ }^{1}$ Both genetic and environmental factors contribute to the risk of CD. ${ }^{2}$ 
Global prevalence of CD has been estimated to be $0.7 \%$ with considerable variation between countries. ${ }^{3}$ Prevalence has increased significantly in recent decades in some developed countries, ${ }^{4,5}$ and serological studies show that a substantial portion of this increase in prevalence is real, in that it is not solely due to factors such as increased awareness and testing. ${ }^{6-8}$ As genetic factors do not change over short time periods, there is a consensus that this rise in real prevalence of $\mathrm{CD}$ is due to environmental factors. ${ }^{2,9}$ Yet, the environmental factors in the existing literature do not appear to provide a satisfactory explanation for this increase in real prevalence. ${ }^{2,9,10}$ As Ludviggson and Green have suggested, there is a "missing environmental factor" in $\mathrm{CD},{ }^{10}$ and it is crucial that this factor be identified. ${ }^{10}$ Others have echoed this sentiment. ${ }^{2,9}$

Vitamin D is a secosteroid that has a number of biological effects including regulating calcium absorption and modulation of the immune system. ${ }^{11}$ Two forms are 1,25-dihydroxyvitamin $\mathrm{D}\left[1,25(\mathrm{OH})_{2} \mathrm{D}\right]$ and its precursor, 25-hydroxyvitamin D [25(OH)D]. ${ }^{12}$ While the level of $25(\mathrm{OH}) \mathrm{D}$ in plasma is commonly used as an indication of vitamin $\mathrm{D}$ status, it is $1,25(\mathrm{OH})_{2} \mathrm{D}$, which is the biologically active form of vitamin D. ${ }^{12}$ Vitamin $\mathrm{D}$ can be ingested orally and absorbed through the digestive tract or synthesized in the skin through sunlight exposure. ${ }^{12}$ Oral vitamin D supplementation, even in modest doses, generally has a greater effect on plasma levels of vitamin D than sunlight exposure. ${ }^{13}$

Based on evidence from the literature that will be explored in this article, elevation in plasma levels of $1,25(\mathrm{OH})_{2} \mathrm{D}$ is hypothesized to be a significant missing risk factor for CD. Specifically, the author proposes that in a substantial number of cases of $\mathrm{CD}$, three primary factors are involved in the induction of the disease. These three factors are: 1) gluten exposure, 2) genetic predisposition in the form of the genetic variant human leukocyte antigen (HLA) DQ2 or HLA DQ8, and 3) elevated levels of $1,25(\mathrm{OH})_{2} \mathrm{D}$ in plasma. As gluten exposure is a necessary condition for the development of $\mathrm{CD},{ }^{1}$ and at least one of the two genetic variants HLA DQ2 or HLA DQ8 is present in almost all cases of $\mathrm{CD},{ }^{1}$ the novel part of this hypothesis is the third factor. Consumption of oral vitamin $\mathrm{D}$ raises plasma levels of $1,25(\mathrm{OH})_{2} \mathrm{D}$ in a dose-dependent manner. ${ }^{14}$ Therefore, a corollary to the above hypothesis is that significant exposure to oral vitamin D through supplementation, fortification, or a combination will increase the risk of $\mathrm{CD}$ in those who are exposed to gluten and have at least one of the genetic variants that are associated with $\mathrm{CD}$.
Some of the concepts and evidence explored in the present article were initially proposed in a much less developed form 4 years ago in a paper by the author. ${ }^{15}$ Additional evidence was obtained and analyzed as part of a retrospective survey study by the author and a collaborator on risk factors for CD in children. ${ }^{16}$ The present article further develops this hypothesis, provides additional evidence for it from the literature, and explores how it may explain a number of features of $C D$ epidemiology.

\section{Plasma Levels of $\mathrm{I,25}(\mathrm{OH})_{2} \mathrm{D}$ and CD}

Plasma levels of $25(\mathrm{OH}) \mathrm{D}$ are often low in adults with $\mathrm{CD}$ who are not on a gluten-free diet (GFD). ${ }^{17,18}$ Based on this, it is a common medical practice to test plasma levels of $25(\mathrm{OH})$ $\mathrm{D}$ in $\mathrm{CD}$ patients and prescribe supplemental oral vitamin $\mathrm{D}$ to those who have low levels of this metabolite in plasma. ${ }^{19,20}$ However, the low plasma levels of $25(\mathrm{OH}) \mathrm{D}$ that sometimes occur in CD will usually normalize after some time on a GFD without vitamin D supplementation. ${ }^{17,21}$

Plasma levels of $1,25(\mathrm{OH})_{2} \mathrm{D}$ are often elevated in $\mathrm{CD}$, and this is especially true in those who are not on a GFD. ${ }^{17,22,23}$ In contrast to $25(\mathrm{OH}) \mathrm{D}$, the elevation in plasma levels of $1,25(\mathrm{OH})_{2} \mathrm{D}$ in $\mathrm{CD}$ often does not completely normalize, even for those on a GFD. ${ }^{17,23}$ For example, Corrazza et al found that median plasma levels of $25(\mathrm{OH}) \mathrm{D}$ in those with $\mathrm{CD}$ on a GFD are just $9 \%$ lower than controls, while median plasma levels of $1,25(\mathrm{OH})_{2} \mathrm{D}$ in those with $\mathrm{CD}$ on a GFD are $68 \%$ higher than controls. ${ }^{17}$ Separately, Selby et al in a cohort of 35 middle-aged patients with CD on a GFD, who had been diagnosed on average about 10 years previously, found that no cases had levels of $25(\mathrm{OH}) \mathrm{D}$ that were below the reference range and $44 \%$ of cases had levels of $1,25(\mathrm{OH})_{2}$ $\mathrm{D}$ that were above the reference range. ${ }^{23}$

Yet, as mentioned in the Introduction, $1,25(\mathrm{OH})_{2} \mathrm{D}$ is the biologically active form of vitamin D. ${ }^{12}$ Based on this fact and the evidence above that this metabolite is often elevated in $\mathrm{CD}$, the rationale for vitamin $\mathrm{D}$ supplementation in $\mathrm{CD}$ seems questionable. Zingone and Ciacci have made this same observation. ${ }^{24}$ The elevation in $1,25(\mathrm{OH})_{2} \mathrm{D}$ that is often observed in CD has traditionally been attributed to secondary hyperparathyroidism due to inadequate absorption of calcium. $^{18,23}$ To the author, this seems unlikely to be a significant factor after treatment on a GFD as serum calcium levels are generally unremarkable in those with $\mathrm{CD}$ on a GFD, even when the plasma levels of $1,25(\mathrm{OH})_{2} \mathrm{D}$ are high. ${ }^{17,23}$ Another possibility is that some portion of the 
elevation in plasma levels of $1,25(\mathrm{OH})_{2} \mathrm{D}$ that persists in some of those with CD years after initiating a GFD was present prior to the development of $\mathrm{CD}$ in these individuals.

\section{Conditions That Cause Elevated $\mathrm{I}, 25(\mathrm{OH})_{2} \mathrm{D}$ and CD Risk}

Many conditions in the medical literature cause elevations in $1,25(\mathrm{OH})_{2} \mathrm{D}$ in plasma. For at least nine such conditions, there are indications in the medical literature of comorbidity with $\mathrm{CD}$. Table 1 enumerates these nine conditions, and for each condition it provides the magnitude of the elevation in $1,25(\mathrm{OH})_{2} \mathrm{D}$ relative to controls, information on the comorbidity with $\mathrm{CD}$, and the odds ratio (OR) and $95 \%$ confidence interval (CI) for $\mathrm{CD}$. The ORs in Table 1 are mostly expressed for the outcome of $\mathrm{CD}$ subsequent to the diagnosis of the condition in question. For some of the conditions in Table 1, an OR for CD has not been published in the literature. In two such conditions, ORs and CIs were calculated using data from the literature with standard formulas; ${ }^{25}$ in two other conditions, ORs were approximated by risk ratios (RRs) from the literature using the rare disease assumption; ${ }^{26}$ and in one condition, an OR was approximated by an RR from the literature using the rare disease assumption and the commutative nature of ORs. ${ }^{26,27}$

Table 1 does not include conditions where the elevation in plasma levels of $1,25(\mathrm{OH})_{2} \mathrm{D}$ is merely associated with the condition, rather than being a result of the condition. For example, elevation in $1,25(\mathrm{OH})_{2} \mathrm{D}$ is a risk factor for kidney stones ${ }^{49}$ and kidney stones have significant comorbidity with $\mathrm{CD} .{ }^{50}$ However, since there is no evidence that kidney stones cause the elevation in plasma levels of $1,25(\mathrm{OH})_{2} \mathrm{D}$ that is associated with them, ${ }^{49}$ kidney stones are not included in Table 1.

The nine disparate conditions in Table 1 include genetic conditions (Williams syndrome, Turner syndrome, and Klinefelter syndrome), ${ }^{28,34,45}$ infectious diseases (sarcoidosis and tuberculosis), ${ }^{36,40}$ and other non-infectious diseases (hypothyroidism, primary hyperparathyroidism, lymphoma, and polycystic ovary syndrome [PCOS] $)^{31,38,42,47}$

The elevated plasma levels of $1,25(\mathrm{OH})_{2} \mathrm{D}$ observed in these nine conditions are caused by a variety of mechanisms. In Williams syndrome, the elevated levels of $1,25(\mathrm{OH})_{2} \mathrm{D}$ are due to haploinsufficiency of the WSTF gene, which normally plays an important role in vitamin D homeostasis. ${ }^{28,51}$ The elevated levels of $1,25(\mathrm{OH})_{2} \mathrm{D}$ observed in sarcoidosis, tuberculosis, and lymphoma are caused by macrophage activation due to the underlying disease. ${ }^{52-54}$ In sarcoidosis and tuberculosis, the disease is bacterial, ${ }^{52,53}$ and in lymphoma, the disease is cancer. ${ }^{54}$

The elevated levels of $1,25(\mathrm{OH})_{2} \mathrm{D}$ observed in primary hyperparathyroidism are due to high levels of parathyroid hormone, which upregulates the conversion of 25 $(\mathrm{OH}) \mathrm{D}$ to $1,25(\mathrm{OH})_{2} \mathrm{D}^{47,55}$ In the case of primary hyperparathyroidism, the high levels of parathyroid hormone are generally caused by an adenoma, a non-cancerous tumor on the parathyroid gland. ${ }^{56}$

Table I Conditions That Cause Elevated I,25(OH $)_{2} \mathrm{D}$ in Plasma and Have Indications of Comorbidity with CD

\begin{tabular}{|c|c|c|c|}
\hline Condition & $\begin{array}{l}\mathrm{I}, 25(\mathrm{OH})_{2} \mathrm{D} \text { in Plasma } \\
\text { (\% Higher Relative to } \\
\text { Controls) }\end{array}$ & CD Comorbidity & OR of CD \\
\hline Williams syndrome & $602^{\mathrm{a}, 28,29}$ & $9.4 \%$ with Williams syndrome have $C D^{30}$ & $19.36(8.15-46.02)$ \\
\hline Lymphoma & $107^{\mathrm{b}, 31,32}$ & RR $2.4(0.7-8.5)$ for CD after or with lymphoma ${ }^{33}$ & $2.4(0.7-8.5)$ \\
\hline Turner syndrome & $91^{\mathrm{c}, 29,34}$ & $6.4 \%$ with Turner syndrome have $C D^{35}$ & $12.63(8.03-19.89)$ \\
\hline Sarcoidosis & $88^{d, 36}$ & OR $3.58(1.98-6.45)$ for $C D$ after sarcoidosis ${ }^{37}$ & $3.58(1.98-6.45)$ \\
\hline Hypothyroidism & $74^{38}$ & OR $2.20(\mid .2 I-4.0 I)$ for undiagnosed $C D^{39}$ & $2.20(1.21-4.01)$ \\
\hline Tuberculosis & $49^{40}$ & OR $2.50(1.75-3.55)$ for CD after tuberculosis ${ }^{4 I}$ & $2.50(1.75-3.55)$ \\
\hline Polycystic ovary syndrome & $35^{e, 42}$ & $\begin{array}{l}\text { 3x greater IgG seropositivity for gliadin; }{ }^{43} \text { infertility often } \\
\text { comorbid with } C D^{44}\end{array}$ & Likely > I \\
\hline Klinefelter syndrome & $30^{f, 45}$ & RR $3.0(0.8-7.8)$ for $C D^{46}$ & $3.0(0.8-7.8)$ \\
\hline PHPT & $27^{47}$ & RR I.9I (I.44-2.52) for PHPT, 5 years after $C D^{48}$ & $1.91(1.44-2.52)$ \\
\hline
\end{tabular}

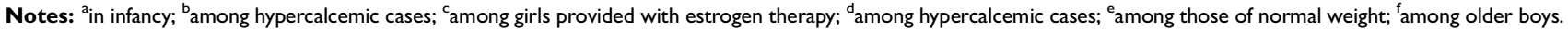
Abbreviations: I,25(OH) 2 D, I,25-dihydroxyvitamin D; CD, celiac disease; IgG, immunoglobulin G; OR, odds ratio; PHPT, primary hyperparathyroidism; RR, risk ratio. 
Likewise, elevated levels of parathyroid hormone are a characteristic of hypothyroidism, ${ }^{38}$ Turner syndrome, ${ }^{57}$ Klinefelter syndrome, ${ }^{45}$ and some cases of PCOS. ${ }^{42}$ As parathyroid upregulates conversion to $1,25(\mathrm{OH})_{2} \mathrm{D}$ as previously mentioned, ${ }^{47,55}$ it seems certain that the elevation of $1,25(\mathrm{OH})_{2} \mathrm{D}$ observed in these conditions is at least partly caused by the elevated levels of parathyroid hormone that are common to them. In Turner syndrome and Klinefelter syndrome, the hormone replacement therapy that is often provided to patients with these conditions also contributes to elevation in $1,25(\mathrm{OH})_{2} \mathrm{D}$. Specifically, it is considered best medical practice for Turner syndrome patients to receive estrogen and for Klinefelter syndrome patients to receive testosterone, ${ }^{58,59}$ and each of these therapies increases plasma levels of $1,25(\mathrm{OH})_{2} \mathrm{D}^{34,60}$

For eight of the nine conditions in Table 1, there is evidence in the literature that the condition in question often precedes the development of CD in cases of comorbidity. As Williams syndrome, Turner syndrome, and Klinefelter syndrome are all genetic conditions that are present prior to birth, ${ }^{28,34,45}$ and CD cannot be present prior to gluten exposure, ${ }^{1}$ it is clear that these three genetic conditions precede the development of $\mathrm{CD}$ in cases of comorbidity.

For the conditions that are not purely genetic, the relationship is less clear. While $\mathrm{CD}$ is typically viewed as a risk factor for lymphoma, ${ }^{33}$ the converse is also true. Specifically, patients who are diagnosed with lymphoma are at greater risk of being diagnosed with $\mathrm{CD}$ after or simultaneously with a diagnosis of lymphoma. ${ }^{33}$ Similarly, $\mathrm{CD}$ is sometimes viewed as a risk factor for tuberculosis, but a population-based study shows that tuberculosis is a risk factor for subsequent diagnosis of $\mathrm{CD} .{ }^{41}$ Likewise, $\mathrm{CD}$ is typically viewed as a risk factor for primary hyperparathyroidism. ${ }^{48}$ However, much of the increased risk of diagnosis of primary hyperparathyroidism following a diagnosis of $\mathrm{CD}$ occurs in the first year following $\mathrm{CD}$ diagnosis, which suggests that CD may have "unmasked" unrecognized cases of primary hyperparathyroidism. ${ }^{48}$ In hypothyroidism, undiagnosed $\mathrm{CD}$ is about 2.2 times as common as in the general population. ${ }^{39}$ Likewise, prior diagnosis of sarcoidosis is associated with subsequent diagnosis of $\mathrm{CD}^{37,61}$

With PCOS, there are indications of an association but limited data on whether PCOS precedes or follows CD. Specifically, a small study found that immunoglobulin $\mathrm{G}$ positive antibodies to gliadin are about three times more common among those with PCOS than controls, but biopsy did not confirm this association. ${ }^{43}$ Yet separate research shows that there is a significant association between female infertility and $\mathrm{CD},{ }^{44}$ and PCOS is the cause of about $70 \%$ of the cases of anovulatory infertility. ${ }^{62}$

At least four of the conditions in Table 1 are significantly more common in adults than children. Specifically, sarcoidosis and primary hyperparathyroidism are much more common in those who are of age 40 or over, ${ }^{63,64}$ and the risk of tuberculosis and lymphoma increases with age. ${ }^{65,66}$

Interestingly, among the conditions in Table 1, there is a correlation between the average level of $1,25(\mathrm{OH})_{2} \mathrm{D}$ in plasma relative to controls and the magnitude of comorbidity with $\mathrm{CD}$ as measured through the OR. Specifically, the Pearson correlation coefficient between these two columns in Table 1 is 0.858 , and the p-value is 0.006 . PCOS was excluded from this analysis as its $\mathrm{OR}$ with $\mathrm{CD}$ is unknown. While this correlation is strong, the data suggest that Klinefelter syndrome and especially Turner syndrome have relatively high ORs for CD compared to the levels of $1,25(\mathrm{OH})_{2} \mathrm{D}$ that are observed in these conditions. If elevation in $1,25(\mathrm{OH})_{2} \mathrm{D}$ is a causative risk factor for $\mathrm{CD}$, higher ORs might be expected for these two genetic conditions than indicated by a point in time analysis of plasma levels of $1,25(\mathrm{OH})_{2} \mathrm{D}$ due to the lifelong persistence of these two conditions and volatility in $1,25(\mathrm{OH})_{2} \mathrm{D}$ levels from hormone replacement that is commonly provided as treatment for them.

\section{Vitamin D Supplementation and CD}

Animal studies show that vitamin D supplementation in extremely high doses can have significant negative gastrointestinal effects, and these effects or variants of them are often observed in $\mathrm{CD}$ in humans. For example, high-dose vitamin D supplementation in mice increases the propensity for colitis and decreases bacterial diversity in the microbiome ${ }^{67} \mathrm{CD}$ and colitis have significant comorbidity, ${ }^{68}$ and decreased bacterial diversity of the microbiome is a characteristic of $\mathrm{CD}^{69}$ Extremely high-dose chronic oral vitamin $\mathrm{D}$ exposure in rats, at doses that are eventually lethal, causes sloughing of the intestinal villi. ${ }^{70}$ Flattened intestinal villi are one of the defining characteristics of $\mathrm{CD}^{71}$

Three human studies have directly measured the impact of oral vitamin D supplementation on CD risk in modest doses. First, a multi-site diabetes study examined the effects of prenatal supplementation on $\mathrm{CD}$ risk. ${ }^{72}$ Second, a Norwegian cohort study examined the effects of supplementation up to 18 months of age and prenatal 
supplementation on $\mathrm{CD}$ risk. ${ }^{73}$ Third, a retrospective US survey study by the author and collaborator examined the effects of supplementation in infancy and between ages 2 and 3 years on $\mathrm{CD}$ risk. ${ }^{16}$

The multi-site diabetes study concluded that there was no association between prenatal vitamin $\mathrm{D}$ supplementation and CD risk. ${ }^{72}$ The Norwegian cohort study found no association between supplementation up to 18 months of age and CD risk or prenatal supplementation and $\mathrm{CD}$ risk. ${ }^{73}$ The retrospective study by the author and a collaborator found a statistically significant association between vitamin $\mathrm{D}$ supplementation for greater than 3 months in infancy and $\mathrm{CD}$ risk but found no association between supplementation between ages 2 and 3 and $\mathrm{CD}$ risk. ${ }^{16}$

Superficially, these three human studies would seem to provide only modest support for a connection between vitamin $\mathrm{D}$ supplementation and $\mathrm{CD}$ risk. However, additional analysis is revealing. Regarding the multi-site diabetes study, it actually found an association between any prenatal vitamin D supplementation and CD autoimmunity in the child with a p-value of $0.04 .^{72}$ The authors of this multi-site study did not appear to view this result as worthy of comment, likely because other measures of vitamin D supplementation from this same study were not observed to have statistically significant associations with $\mathrm{CD}$ or $\mathrm{CD}$ autoimmunity. As maternal vitamin supplementation is associated with supplementation in childhood, ${ }^{74}$ one might interpret this finding from the multi-site study as providing some support for the hypothesis that vitamin D supplementation in infancy is associated with $\mathrm{CD}$.

Regarding the Norwegian cohort study, while the underlying dataset was large, the subset on which the analysis was conducted consisted of 416 cases and 570 controls, and many of these had missing data for some variables. ${ }^{73}$ Specifically, of these, 108 cases and 176 controls were missing data on vitamin D supplementation, ${ }^{73}$ which represents a disproportionately greater share of controls than cases. If vitamin D supplementation among those with missing data for this variable differed materially in aggregate from those where data were present, this could impact the results.

During the majority of years when data for this Norwegian cohort study were gathered, the recommended daily intake of vitamin D in Norway was 5 micrograms, which is equivalent to 200 international units (IU), ${ }^{75,76}$ and during the remaining years, the recommended daily intake of vitamin D was 7.5 micrograms. ${ }^{75}$ Subsequent to the data collection period, the recommended daily intake in Norway was raised to 10 micrograms. ${ }^{75}$ Also, it was and is a common practice in Norway to provide supplemental vitamin D through cod liver oil capsules. ${ }^{77,78}$ Thus, any effect of vitamin D supplementation on CD risk may be obscured or reduced in this study, if 200 IU is not a material dose with respect to risk, or if other compounds in cod liver oil have confounding effects on CD risk.

Regarding the result on supplementation among 2- to 3 -year-olds from the survey study by the author and a collaborator, the study did not collect information on the dose of vitamin D provided through supplementation or the quantity of vitamin $\mathrm{D}$ consumed through fortified foods. ${ }^{16}$

With respect to the dose, multivitamin supplements for children typically provide much smaller doses of vitamin $D$ per pound than infant vitamin $\mathrm{D}$ drops provide to an infant. Specifically, as of 2008, multivitamins in the US for young children typically contained between $200 \mathrm{IU}$ and $400 \mathrm{IU}$ of vitamin $\mathrm{D},{ }^{79}$ while vitamin $\mathrm{D}$ drops for infants typically provided doses of $400 \mathrm{IU}$ of vitamin $\mathrm{D} .{ }^{80}$ Thus, if used as directed, a 2- to 3-year-old child would receive an equal or slightly smaller dose than an infant, but a 2- to 3-year-old typically weighs over twice as much as a 3-month-old infant. ${ }^{81}$ Hence, the typical dose of vitamin $\mathrm{D}$ per pound in infancy from vitamin D drops will be much greater than what a 2- to 3-year-old would receive through a multivitamin.

Other studies have found associations between oral vitamin D supplementation in infancy and the risk of atopic dermatitis and asthma. ${ }^{82-85}$ Both of these conditions have comorbidity with $\mathrm{CD} .{ }^{86,87}$ As comorbidity suggests the possibility of a common underlying risk factor, and vitamin D supplementation in infancy is associated with both of these conditions, these findings serve as additional circumstantial evidence that vitamin D supplementation in infancy may be a risk factor for CD.

Some additional studies in the literature that highlight the effects of oral vitamin D supplementation on the gastrointestinal tract are worthy of highlighting in this context. First, in a study designed to test the effects of vitamin D supplementation on bone in prepubescent girls, one of the participants who received supplemental vitamin $\mathrm{D}$ dropped out of the study due to the development of $\mathrm{CD} .{ }^{88} \mathrm{It}$ is possible that this finding of a single case of $\mathrm{CD}$ onset during a vitamin D supplementation trial could be coincidental, but it is tantalizing given the evidence that oral vitamin $\mathrm{D}$ supplementation in infancy may be associated with CD. Second, some trials of high-dose vitamin D supplementation have inadvertently 
highlighted that vitamin D supplementation causes constipation in some of the population. In some trials, researchers acknowledged that constipation was a complaint of a modest number of the participants, ${ }^{89-91}$ and in at least one trial constipation was found to be a statistically significant outcome in the highest dose cohort. ${ }^{92}$ Constipation has become an increasingly common symptom of CD in recent decades and as of 2013 was a symptom of CD in $27 \%$ of Finnish children at the time of diagnosis. ${ }^{93}$ This data suggest that significant vitamin D supplementation is a risk factor for constipation, and constipation and $\mathrm{CD}$ are often comorbid. As comorbidity suggests the possibility of a common risk factor, the above is consistent with the hypothesis that significant vitamin D supplementation may be a risk factor for $\mathrm{CD}$ as well.

To summarize this section, evidence from animal studies suggests that high-dose vitamin D supplementation has significant negative gastrointestinal effects that are characteristic of CD. Evidence in human studies is mixed, but one human study found a statistically significant association between vitamin D supplementation for greater than 3 months in infancy and CD, and another study found an association between a measure of any prenatal vitamin D supplementation and CD autoimmunity in the child. In addition, the literature suggests that significant vitamin D supplementation in infancy is associated with two conditions that are often comorbid with $\mathrm{CD}$, which is supportive of the hypothesis that vitamin $\mathrm{D}$ supplementation in infancy is associated with CD.

\section{Select Effects of Vitamin D on the Immune System}

The effects of $1,25(\mathrm{OH})_{2} \mathrm{D}$ on the immune system are complex. ${ }^{94}$ One of its effects is to upregulate allergic response to foreign proteins. $^{95}$ In mice, injections of $1,25(\mathrm{OH})_{2}$ $\mathrm{D}$ coincident to exposure to egg albumin have been found to increase the production of immunoglobulin $\mathrm{E}$ and upregulate interleukin (IL) 13, a proinflammatory cytokine. ${ }^{95}$ In baby pigs, high-dose vitamin D supplementation significantly increases the number of leukocytes in blood and upregulates mucosal antimicrobial activity. ${ }^{96}$ These findings are consistent with in vitro studies on human macrophages, which also show that $1,25(\mathrm{OH})_{2} \mathrm{D}$ upregulates antibacterial immune activity. ${ }^{97,98}$ Separately, Leonard et al have suggested that the initiation of CD may be due to the immune system confusing the gliadin proteins in gluten with a pathogenic bacteria. ${ }^{99}$ In this light, it is conceivable that increased antibacterial immune activity in the mucosa of the small intestine caused by high plasma levels of $1,25(\mathrm{OH})_{2} \mathrm{D}$ may increase the risk of a dysfunctional immune reaction to gliadin in this same tissue, which may ultimately result in CD autoimmunity.

While the above seems plausible, much of the medical literature on vitamin D suggests that greater vitamin $\mathrm{D}$ exposure leads to less inflammation and more measured immune response. ${ }^{100,101}$ However, many of the studies in the literature on vitamin D and the immune system have some substantial limitations. First, some studies are observational and only measure the $25(\mathrm{OH}) \mathrm{D}$ metabolite, ${ }^{102,103}$ and relatedly, it is the $25(\mathrm{OH}) \mathrm{D}$ metabolite that is typically used to define deficiency. ${ }^{12}$ Yet, as previously highlighted, $1,25(\mathrm{OH})_{2} \mathrm{D}$ is the active vitamin $\mathrm{D}$ metabolite, ${ }^{12}$ and in $\mathrm{CD}, 25(\mathrm{OH}) \mathrm{D}$ can be low or normal, while $1,25(\mathrm{OH})_{2}$ D may be high. ${ }^{17,22,23}$ Thus, observational studies which use the typical definition of vitamin D deficiency are likely to produce questionable results in the context of $\mathrm{CD}$.

Second, some studies that analyze the effects of vitamin $\mathrm{D}$ on the immune system are in vitro studies. ${ }^{97,98,100,101}$ While these have real value in illuminating the functions of the various components of the immune system, due to the complexity of the immune system and how real-world exposures may interact with it, in vivo studies are likely to be more reliable indications of real-world effects. ${ }^{104}$

Third, some studies on the effects of oral vitamin $\mathrm{D}$ exposure are based on protocols that use modest doses of vitamin D. ${ }^{105,106}$ While such studies may be safer for participants than studies with larger doses, a stronger signal on effect will undoubtedly be observed through studies that use larger doses.

Table 2 includes some of the effects on the immune system of very high-dose vitamin D supplementation in humans from a non-systematically selected subset of studies in the literature. One of the studies is based on supplementation with $1,25(\mathrm{OH})_{2}$ $\mathrm{D}$ rather than $25(\mathrm{OH}) \mathrm{D},{ }^{107}$ and two measure effects in umbilical cord blood after significant maternal vitamin D supplementation. ${ }^{109,112}$ Collectively this set of studies suggests that in very high doses vitamin D upregulates many of the cytokines, chemokines, and toll-like receptors that are associated with immune activation and relatedly are also associated with CD. Specifically, these studies show that oral vitamin D in very large doses upregulates TLR2, TLR4, IL-17A, CCR4, CXCR4, IL12RB1, IL12RB2, and TGF beta. ${ }^{107,109,112,113,115}$

The upregulation of each of these has also been observed in CD. ${ }^{99,108,110,111,114}$

While the doses involved in these studies are very large, the direction of association suggests that in those 
Table 2 Select Human Trials of High-Dose Vitamin D Supplementation and Its Effects

\begin{tabular}{|c|c|c|c|c|}
\hline Study & Population & $\begin{array}{l}\text { Vitamin } \\
\text { D Exposure }\end{array}$ & Select Findings & $\begin{array}{l}\text { Findings on CD } \\
\text { from Literature }\end{array}$ \\
\hline Protiva et al ${ }^{107}$ & $\begin{array}{l}\text { Adults at risk of } \\
\text { cancer }\end{array}$ & $\begin{array}{l}\text { Supplementation with } \\
\mathrm{I}, 25(\mathrm{OH})_{2} \mathrm{D} \text { at } 10 \mathrm{IU} \\
\text { per day }\end{array}$ & $\begin{array}{l}\text { "Striking upregulation of genes involved in } \\
\text { immune responses, inflammation, } \\
\text { extracellular matrix, and cell adhesion" in the } \\
\text { rectosigmoid mucosa. }\end{array}$ & $\begin{array}{l}\text { Genes associated } \\
\text { with inflammatory } \\
\text { response } \\
\text { upregulated. }^{108}\end{array}$ \\
\hline Hornsby et al ${ }^{109}$ & Pregnant women & $\begin{array}{l}4400 \text { IU per day vs } \\
400 \text { IU per day }\end{array}$ & $\begin{array}{l}\text { In cord blood from neonates, } 4400 \text { IU per day } \\
\text { increased expression of TLR2, TLR4, and IL- } \\
\text { I7A. }\end{array}$ & $\begin{array}{l}\text { Increased TLR2 and } \\
\text { TLR4 expression, }{ }^{10} \\
\text { and IL-I7A } \\
\text { upregulation. }{ }^{\prime \prime \prime}\end{array}$ \\
\hline Akhtar et al ${ }^{1 / 2}$ & $\begin{array}{l}\text { Pregnant Bangladeshi } \\
\text { women }\end{array}$ & $\begin{array}{l}35,000 \mathrm{IU} \text { per week } \\
\text { vs placebo during } \\
\text { third trimester }\end{array}$ & $\begin{array}{l}\text { In cord blood from neonates, } 35,000 \text { IU per } \\
\text { week increased expression of TNF alpha, INF } \\
\text { gamma, CCR4 gene, CXCR4 gene, ILI2RBI } \\
\text { gene, and the ILI2RB2 gene. }\end{array}$ & $\begin{array}{l}\text { Upregulation of } \\
\text { CCR4, CXCR4, } \\
\text { ILI } 2 R B I \text {, and } \\
\text { ILI } 2 \text { RB2 gene } \\
\text { activity. }{ }^{.9}\end{array}$ \\
\hline $\begin{array}{l}\text { Goncalves-Mendes } \\
\text { et al }{ }^{1 / 3}\end{array}$ & $\begin{array}{l}\text { Vitamin D deficient } \\
\text { elderly }\end{array}$ & $\begin{array}{l}100,000 \text { IU per } 15 \\
\text { days vs placebo over } \\
3 \text { months with } \\
\text { influenza vaccine }\end{array}$ & Higher levels of TGF beta in plasma. & $\begin{array}{l}\text { Higher levels of TGF } \\
\text { beta in lamina } \\
\text { propia. }^{114}\end{array}$ \\
\hline Bak et al ${ }^{115}$ & Ten healthy adults & $\begin{array}{l}480,000 \text { IU over } 15 \\
\text { days }\end{array}$ & $\begin{array}{l}\text { Increased RNA expression of TGF beta and } \\
\text { TNF alpha. }\end{array}$ & $\begin{array}{l}\text { Higher levels of TGF } \\
\text { beta in lamina } \\
\text { propia. }^{114}\end{array}$ \\
\hline
\end{tabular}

Abbreviations: I,25(OH) 2 D, I,25-dihydroxyvitamin D; CCR4, C-C chemokine receptor type 4; CD, celiac disease; CXCR4, C-X-C chemokine receptor type 4; IL-I7A, interleukin I7A; IU, international units; TGF beta, transforming growth factor beta; TLR2, toll-like receptor 2; TLR4, toll-like receptor 4; TNF alpha, tumor necrosis factor alpha; vs, versus.

whose plasma levels of $1,25(\mathrm{OH})_{2} \mathrm{D}$ are already elevated or are predisposed to elevation, more modest doses of oral vitamin D may induce a state of increased immune activation that puts such individuals at greater risk for onset of CD. This possibility that small doses of oral vitamin $\mathrm{D}$ will have an outsized effect on immune activity seems especially likely to occur in those who are later diagnosed with $\mathrm{CD}$, since a large subset of those who are diagnosed with $\mathrm{CD}$ have significantly elevated plasma levels of $1,25(\mathrm{OH})_{2} \mathrm{D}$ independent of supplementation. ${ }^{17,22,23}$

\section{Epidemiology of CD and Vitamin D Exposure}

$\mathrm{CD}$ epidemiology has a number of idiosyncrasies that appear in the literature, many of which superficially seem improbable. Table 3 catalogs thirteen of these features and how the hypothesized association between elevated $1,25(\mathrm{OH})_{2} \mathrm{D}$ and $\mathrm{CD}$ or relatedly the hypothesized association between vitamin $\mathrm{D}$ supplementation and $\mathrm{CD}$ could provide an explanation for each.

\section{Other Hypotheses}

The strength of this vitamin D hypothesis as a significant missing risk factor for $\mathrm{CD}$ is especially evident when one compares the breadth of its explanatory power to other hypotheses that have been proposed in the literature. Three such hypotheses are examined in this section.

First, some researchers have suggested that the hygiene hypothesis may explain the increased prevalence of $\mathrm{CD} .{ }^{134}$ According to this hypothesis, decreased exposure to parasites and infections, especially in the young, negatively impacts the development of the immune system, and as a result increases the risk of $\mathrm{CD}$ and other immunemediated diseases in later life. ${ }^{134,155}$ While the hygiene hypothesis could conceivably provide an explanation for the differential in $\mathrm{CD}$ prevalence between Finnish and Russian Karelians, ${ }^{134}$ some other major features of $\mathrm{CD}$ epidemiology from Table 3 do not bear it out. For example, consider the Swedish CD epidemic. The literature shows that its inception was in $1984 .{ }^{116}$ If the hygiene hypothesis played a major role in $\mathrm{CD}$ epidemiology, then one would expect significant increases in $\mathrm{CD}$ prevalence as exposure to 


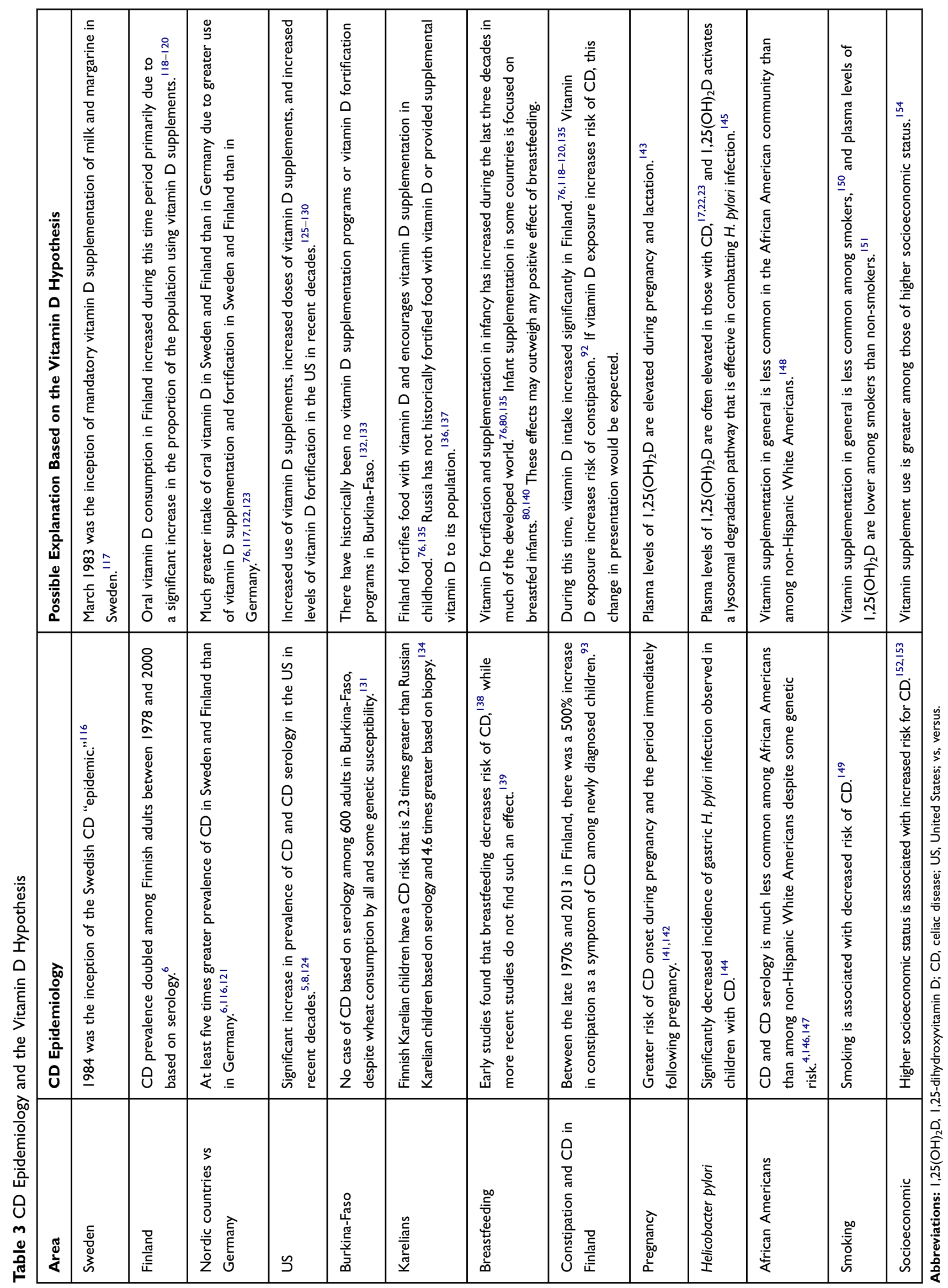


intestinal parasites diminished with the advent of household plumbing and the modern toilet. ${ }^{156}$ These advances in hygiene occurred gradually in Sweden in urban settings in the early and middle decades of the twentieth century. ${ }^{157,158}$ Thus, the timing and rapid advance of the Swedish CD epidemic starting in $1984^{116}$ would not appear to be explainable using the hygiene hypothesis. Also, recall that the prevalence of $\mathrm{CD}$ is more than five times higher in Sweden than in Germany. ${ }^{116,121}$ If this feature of CD epidemiology is due to the hygiene hypothesis, then Sweden must be significantly more hygienic than Germany. As Sweden and Germany are both highly developed European countries, and Germany's spending on healthcare per capita is marginally higher than Sweden's is, ${ }^{159}$ this seems improbable.

Second, some researchers have suggested that increased exposure to the pesticide glyphosate may explain the increased prevalence of $\mathrm{CD} .{ }^{160}$ Consider this hypothesis in the context of Sweden, Finland, and Germany. As previously mentioned, prevalence of CD in Sweden and Finland is about five times higher than in Germany. ${ }^{6,116,121}$ If glyphosate is a significant factor in this feature of CD epidemiology, then one would expect negligible glyphosate exposure among those living in Germany and significant glyphosate exposure among those living in Sweden and Finland. Yet, in 1997, glyphosate became the only herbicide used on the German railway system. ${ }^{161}$ In the same year, glyphosate was observed in the surface water of two rivers in the NorthRhine-Westphalia state of Germany at a maximum concentration of $590 \mathrm{ng} / 1,{ }^{162}$ and as of 2009 , glyphosate was applied to $39 \%$ of all of the arable land in Germany. ${ }^{163}$ A groundwater survey in the mid-2000s found no indication that glyphosate exposure was significantly lower in Germany than in Sweden or Finland. ${ }^{164}$ Specifically, glyphosate was present in $22 \%$ of groundwater samples from Germany, $24.7 \%$ from Sweden, and $11.2 \%$ from Finland. ${ }^{164}$

Third, some researchers have suggested that increased exposure to manufactured transglutaminase enzymes in food may explain the increased prevalence of $\mathrm{CD} .{ }^{165} \mathrm{An}$ issue with this hypothesis is that the introduction of manufactured transglutaminase in food occurred after much of the increase in the prevalence of CD. Specifically, stable transglutaminases were first isolated from bacteria in $1989,{ }^{166}$ and many of the processes to manufacture transglutaminase for the food industry were developed in the early 2000s. ${ }^{167}$ Yet, as previously highlighted, the CD epidemic began in Sweden in $1984,{ }^{116}$ prevalence of CD doubled in Finland between 1978 and 2000, ${ }^{6}$ and a significant portion of the increase in CD prevalence in the US occurred prior to $1989 .{ }^{124}$ Thus, it would appear that manufactured transglutaminase in food was not a significant factor in the increased prevalence of $\mathrm{CD}$ during the latter decades of the twentieth century in some developed countries.

While the above shows that none of these three hypotheses individually can explain the major features of $\mathrm{CD}$ epidemiology as outlined in Table 3, this does not preclude the possibility that one or more of these factors may contribute to CD risk, and perhaps in combination with other factors could explain many of the major features of CD epidemiology.

\section{Summary and Discussion}

Studies highlighted in the section on plasma levels of $1,25(\mathrm{OH})_{2} \mathrm{D}$ show that elevated plasma levels of this metabolite are common in $\mathrm{CD}$ at the time of diagnosis and that in a substantial proportion of cases these elevated levels persist years after transition to a GFD. Separately, as highlighted above, there are nine disparate conditions in the literature, which cause elevations in $1,25(\mathrm{OH})_{2} \mathrm{D}$ through various mechanisms and for which there are indications of an association with $\mathrm{CD}$ in the literature. For eight of these conditions, there is evidence that the condition in question often precedes CD in cases of comorbidity. In the author's opinion, this suggests that the elevated plasma levels of $1,25(\mathrm{OH})_{2} \mathrm{D}$, which is a common feature of these disparate conditions and is often observed generally in $\mathrm{CD}$ near the time of diagnosis, is a causative factor in inducing CD.

As supplementation with oral vitamin $\mathrm{D}$ increases plasma levels of $1,25(\mathrm{OH})_{2} \mathrm{D}$, the above suggests that significant exposure to oral vitamin $\mathrm{D}$ will also increase the risk of $\mathrm{CD}$. Indeed, animal studies show that exposure to very high doses of oral vitamin D will induce some gastrointestinal symptoms that are associated with $\mathrm{CD}$, and a retrospective study by the author and a collaborator confirms that vitamin D supplementation in humans in infancy for greater than 3-months duration is associated with increased risk of $\mathrm{CD}$. Other studies suggest that significant oral vitamin D supplementation in infancy is associated with increased risk of two conditions that are often comorbid with $\mathrm{CD}$. While no study in the literature has found direct evidence that vitamin D supplementation in later life increases the risk of $\mathrm{CD}$, there is evidence that large doses of oral vitamin D induce constipation in some, and constipation is often comorbid with CD. Also, as highlighted in the section on the nine conditions, four of 
the nine conditions, which are associated with increased $\mathrm{CD}$ risk and cause elevations in $1,25(\mathrm{OH})_{2} \mathrm{D}$, are primarily conditions of adulthood. In the author's opinion, this suggests that elevation in plasma levels of $1,25(\mathrm{OH})_{2} \mathrm{D}$ in adulthood, which each of these conditions cause, may also increase CD risk. Since vitamin D supplementation increases the levels of $1,25(\mathrm{OH})_{2} \mathrm{D}$ in plasma as previously mentioned, this supports the hypothesis that significant vitamin D supplementation in adulthood will also increase the risk of $\mathrm{CD}$.

As the section on vitamin $\mathrm{D}$ and the immune system highlights, $1,25(\mathrm{OH})_{2} \mathrm{D}$ upregulates the antibacterial actions of the immune system, and the effects of very high-dose vitamin D supplementation on cytokines, chemokines, and toll-like receptors match key aspects of the immune profile that is typically observed in CD. While such immune activation is generally not evident in empirical studies of vitamin D supplementation in low doses, it seems likely to the author that a subset of individuals, who have high plasma levels of $1,25(\mathrm{OH})_{2} \mathrm{D}$ or have propensity to elevations in $1,25(\mathrm{OH})_{2} \mathrm{D}$, will experience such immune activation with more modest doses of oral vitamin D.

Table 3 in the section on epidemiology and CD shows that the breadth of the evidence that this vitamin D hypothesis may explain about $\mathrm{CD}$ epidemiology is extraordinary. The hypothesis offers a possible explanation for the timing of the inception of the CD epidemic in Sweden, the increased prevalence of $\mathrm{CD}$ in Finland, the significant differential in prevalence between these two countries and Germany, and the apparent absence of CD from Burkina-Faso. The hypothesis also explains some other puzzles of CD epidemiology, including the differential in prevalence between Finnish and Russian Karelians, the trend toward increased incidence of constipation with $\mathrm{CD}$ in Finland, the higher risk of $\mathrm{CD}$ onset during pregnancy, the decreased risk of Helicobacter pylori infection in $\mathrm{CD}$, the decreased risk of $\mathrm{CD}$ among smokers, and some seemingly contradictory results in the literature regarding breastfeeding and $\mathrm{CD}$ risk in children.

The breadth of the epidemiological evidence that the hypothesis explains acts as additional circumstantial evidence for the hypothesis. In addition, the magnitude of the differentials in CD prevalence that the hypothesis explains suggests that oral vitamin $\mathrm{D}$ exposure may be an important variable in $\mathrm{CD}$ risk. By comparison, three other potential explanations from the literature for the increased prevalence of $\mathrm{CD}$ are inconsistent with some major features of $\mathrm{CD}$ epidemiology.

If this vitamin $\mathrm{D}$ and $\mathrm{CD}$ hypothesis is validated, it has profound practical implications. First, the practice of prescribing oral vitamin $\mathrm{D}$ to $\mathrm{CD}$ patients based on the low levels of 25(OH)D in plasma that are often observed in newly diagnosed $\mathrm{CD}$ patients should be reevaluated. Second, among those who do not have CD but do have genetic risk for it, decreasing exposure to the large doses of oral vitamin $\mathrm{D}$ that are frequently consumed in many developed countries may decrease the risk of CD. As this would have important consequences for the health of these individuals with genetic susceptibility, if this hypothesis is validated, practice guidelines should be reevaluated.

\section{Abbreviations}

1,25(OH $)_{2} \mathrm{D}, \quad 1,25$-dihydroxyvitamin $\mathrm{D} ; \quad 25(\mathrm{OH}) \mathrm{D}, \quad 25-$ hydroxyvitamin D; CCR4, C-C chemokine receptor type 4; $\mathrm{CD}$, celiac disease; CI, 95\% confidence interval; CXCR4, C-X-C chemokine receptor type 4; GFD, gluten-free diet; HLA, human leukocyte antigen; IL, interleukin; IL-17A, interleukin 17A; IU, international units; OR, odds ratio; RR, risk ratio; TGF beta, transforming growth factor beta; TLR2, tolllike receptor 2; TLR4, toll-like receptor 4; TNF alpha, tumor necrosis factor alpha; US, United States.

\section{Funding}

This work was self-funded.

\section{Disclosure}

The author declares that he has no competing interest.

\section{References}

1. Ludvigsson JF, Leffler DA, Bai JC, et al. The Oslo definitions for coeliac disease and related terms. Gut. 2012;62(1):43-52. https://dx. doi.org/10.1136\%2Fgutjnl-2011-301346.

2. Lionetti E, Catassi C. The role of environmental factors in the development of celiac disease: what is new? Diseases. 2015;3(4):282-293. doi:10.3390/diseases3040282

3. Singh P, Arora A, Strand TA, et al. Global prevalence of celiac disease: systematic review and meta-analysis. Clin Gastroenterol Hepatol. 2018;16(6):823-836.e2. doi:10.1016/j.cgh.2017.06.037

4. Kang JY, Kang AH, Green A, Gwee KA, Ho KY. Systematic review: worldwide variation in the frequency of coeliac disease and changes over time. Aliment Pharmacol Ther. 2013;38(3):226-245. doi:10.1111/ apt. 12373

5. Ludvigsson JF, Rubio-Tapia A, van Dyke CT, et al. Increasing incidence of celiac disease in a North American population. Am J Gastroenterol. 2013;108(5):818-824. https://dx.doi.org/10.1038\%2Fajg.2013.60

6. Lohi S, Mustalahti K, Kaukinen K, et al. Increasing prevalence of coeliac disease over time. Aliment Pharmacol Ther. 2007;26 (9):1217-1225. doi:10.1111/j.1365-2036.2007.03502.x

7. Myléus A, Ivarsson A, Webb C, et al. Celiac disease revealed in $3 \%$ of Swedish 12-year-olds born during an epidemic. J Pediatr Gastroenterol Nutr. 2009;49(2):170-176. doi:10.1097/MPG.0b013e31818c52cc

8. Rubio-Tapia A, Kyle RA, Kaplan EL, et al. Increased prevalence and mortality in undiagnosed celiac disease. Gastroenterology. 2009;137:88-93. doi:10.1053/j.gastro.2009.03.059 
9. Lebwohl B, Murray JA, Verdú EF, et al. Gluten introduction, breastfeeding, and celiac disease: back to the drawing board. $\mathrm{Am}$ J Gastroenterol. 2016;111(1):12-14. doi:10.1038/ajg.2015.219

10. Ludvigsson JF, Green PH. The missing environmental factor in celiac disease. $N$ Engl $J$ Med. 2014;371(14):1341-1343. doi:10.1056/NEJMe1408011

11. Schwalfenberg GK. A review of the critical role of vitamin D in the functioning of the immune system and the clinical implications of vitamin D deficiency. Mol Nutr Food Res. 2010;55(1):96-108. doi:10.1002/mnfr.201000174

12. Holick MF. Vitamin D status: measurement, interpretation, and clinical application. Ann Epidemiol. 2009;19(2):73-78. https://dx. doi.org/10.1016\%2Fj.annepidem.2007.12.001

13. Moradi S, Shahdadian F, Mohammadi H, Rouhani MH. A comparison of the effect of supplementation and sunlight exposure on serum vitamin D and parathyroid hormone: a systematic review and meta-analysis. Crit Rev Food Sci Nutr. 2019;1-9. doi:10.1080/10408398.2019.1611538

14. Zittermann A, Ernst JB, Birschmann I, Dittrich M. Effect of vitamin D or activated vitamin D on circulating 1,25-dihydroxyvitamin D concentrations: a systematic review and metaanalysis of randomized controlled trials. Clin Chem. 2015;61(12):1484-1494. doi:10.1373/clinchem.2015.244913

15. Bittker S. Exposure to excessive oral vitamin D in youth: a risk factor for celiac disease in later life? J Allergy Asthma (Herbert). 2015;2(2). doi:10.7243/2054-9873-2-2

16. Bittker SS, Bell KR. Potential risk factors for celiac disease in childhood: a case-control epidemiological survey. Clin Exp Gastroenterol. 2019;12:303-319. doi:10.2147/CEG.S210060

17. Corazza GR, Di Sario A, Cecchetti L, et al. Bone mass and metabolism in patients with celiac disease. Gastroenterology. 1995;109(1):122-128. doi:10.1016/0016-5085(95)90276-7

18. Keaveny AP, Freaney R, McKenna MJ, Masterson J, O’Donoghue DP. Bone remodeling indices and secondary hyperparathyroidism in celiac disease. Am J Gastroenterol. 1996;91(6):1226-1231.

19. Mooney PD, Hadjivassiliou M, Sanders DS. Coeliac disease. BMJ. 2014;348:g1561. doi:10.1136/bmj.g1561

20. Kochhar GS, Singh T, Gill A, Kirby DF. Celiac disease: managing a multisystem disorder. Cleve Clin J Med. 2016;83(3):217-227. doi:10.3949/ccjm.83a.14158

21. Mautalen C, González D, Mazure R, et al. Effect of treatment on bone mass, mineral metabolism, and body composition in untreated celiac disease patients. Am J Gastroenterol. 1997;92(2):313-318.

22. Corazza GR, Di Sario A, Cecchetti L, et al. Influence of pattern of clinical presentation and of gluten-free diet on bone mass and metabolism in adult coeliac disease. Bone. 1996;18(6):525-530. doi:10.1016/8756-3282(96)00071-3

23. Selby PL, Davies M, Adams JE, Mawer EB. Bone loss in celiac disease is related to secondary hyperparathyroidism. J Bone Miner Res. 1999;14(4):652-657. doi:10.1359/jbmr.1999.14.4.652

24. Zingone F, Ciacci $\mathrm{C}$. The value and significance of $25(\mathrm{OH})$ and $1,25(\mathrm{OH})$ vitamin $\mathrm{D}$ serum levels in adult coeliac patients: a review of the literature. Dig Liver Dis. 2018;50(8):757-760. doi:10.1016/j. dld.2018.04.005

25. Altman DG. Practical Statistics for Medical Research. London. UK: Chapman \& Hall; 1991.

26. Greenland S, Thomas DC. On the need for the rare disease assumption in case-control studies. Am J Epidemiol. 1982;116(3):547-553. doi:10.1093/oxfordjournals.aje.a113439

27. Bland JM, Altman DG. Statistics notes. The odds ratio. BMJ. 2000;320(7247):1468. https://doi.org/10.1136/bmj.320.7247.1468

28. Garabédian M, Jacqz E, Guillozo H, et al. Elevated plasma 1,25-dihydroxyvitamin D concentrations in infants with hypercalcemia and an elfin facies. $N$ Engl J Med. 1985;312(15):948-952. doi:10.1056/NEJM198504113121503
29. Chesney RW, Rosen JF, Hamstra AJ, DeLuca HF. Serum 1,25-dihydroxyvitamin D levels in normal children and in vitamin D disorders. Am J Dis Child. 1980;134(2):135-139. doi:10.1001/ archpedi.1980.02130140009004

30. Giannotti A, Tiberio G, Castro M, Gambarara M, Dallapiccola B. Coeliac disease in Williams syndrome. J Med Genet. 2001;38 (11):767-768. https://dx.doi.org/10.1136\%2Fjmg.38.11.767

31. Breslau NA, McGuire JL, Zerwekh JE, Frenkel EP, Pak CY. Hypercalcemia associated with increased serum calcitriol levels in three patients with lymphoma. Ann Intern Med. 1984;100(1):1-6. doi:10.7326/0003-4819-100-1-1

32. Lund B, Sørensen OH, Lund B, Agner E. Serum 1,25-dihydroxyvitamin $\mathrm{D}$ in normal subjects and in patients with postmenopausal osteopenia. Influence of age, renal function and oestrogen therapy. Horm Metab Res. 1982;14(5):271-274. doi:10.1055/s-2007-1018990

33. Green PH, Fleischauer AT, Bhagat G, Goyal R, Jabri B, Neugut AI. Risk of malignancy in patients with celiac disease. Am J Med. 2003;115(3):191-195. doi:10.1016/S0002-9343(03)00302-4

34. Mauras N, Vieira NE, Yergey AL. Estrogen therapy enhances calcium absorption and retention and diminishes bone turnover in young girls with Turner's syndrome: a calcium kinetic study. Metab. 1997;46(8):908-913. doi:10.1016/S0026-0495 (97)90078-0

35. Bonamico M, Pasquino AM, Mariani P, et al. Prevalence and clinical picture of celiac disease in Turner syndrome. J Clin Endocrinol Metab. 2002;87(12):5495-5498. doi:10.1210/jc.2002-020855

36. Bell NH, Stern PH, Pantzer E, Sinha TK, DeLuca HF. Evidence that increased circulating 1 alpha, 25-dihydroxyvitamin $\mathrm{D}$ is the probable cause for abnormal calcium metabolism in sarcoidosis. J Clin Invest. 1979;64(1):218-225. doi:10.1172/JCI109442

37. Ludvigsson JF, Wahlstrom J, Grunewald J, Ekbom A, Montgomery SM. Coeliac disease and risk of sarcoidosis. Sarcoidosis Vasc Diffuse Lung Dis. 2007;24(2):121-126. doi:10.1007/s11083-007-9062-4

38. Bouillon R, Muls E, De Moor P. Influence of thyroid function on the serum concentration of 1,25-dihydroxyvitamin D3. J Clin Endocrinol Metab. 1980;51(4):793-797. doi:10.1210/jcem-51-4-793

39. Choung RS, Larson SA, Khaleghi S, et al. Prevalence and morbidity of undiagnosed celiac disease from a community-based study. Gastroenterology. 2017;152(4):830-839.e5. https://dx.doi.org/10. 1053\%2Fj.gastro.2016.11.043

40. Ralph AP, Rashid Ali MRS, William T, et al. Vitamin D and activated vitamin $\mathrm{D}$ in tuberculosis in equatorial Malaysia: a prospective clinical study. BMC Infect Dis. 2017;17(1):312. https://doi.org/10.1186/s12879-017-2314-z

41. Ludvigsson JF, Wahlstrom J, Grunewald J, Ekbom A, Montgomery SM Coeliac disease and risk of tuberculosis: a population based cohort study. Thorax. 2007;62(1):23-28. doi:10.1136/thx.2006.059451

42. Mahmoudi T, Gourabi H, Ashrafi M, Yazdi RS, Ezabadi Z. Calciotropic hormones, insulin resistance, and the polycystic ovary syndrome. Fertil Steril. 2010;93(4):1208-1214. doi:10.1016/j.fertnstert.2008.11.031

43. Kuscu NK, Akcali S, Kucukmetin NT. Celiac disease and polycystic ovary syndrome. Int J Gynaecol Obstet. 2002;79 (2):149-150. doi:10.1016/S0020-7292(02)00241-2

44. Meloni GF, Dessole S, Vargiu N, Tomasi PA, Musumeci S. The prevalence of coeliac disease in infertility. Hum Reprod. 1999;14 (11):2759-2761. doi:10.1093/humrep/14.11.2759

45. Stagi S, Di Tommaso M, Manoni C, Scalini P, Chiarelli F. Bone mineral status in children and adolescents with Klinefelter syndrome. Int J Endocrinol. 2016;2016:3032759. doi:10.1155/ 2016/3032759

46. Seminog OO, Seminog AB, Yeates D, Goldacre MJ. Associations between Klinefelter's syndrome and autoimmune diseases: English national record linkage studies. Autoimmunity. 2014;48(2):125-128. doi:10.3109/08916934.2014.968918 
47. Moosgaard B, Vestergaard P, Heickendorff L, Mosekilde L. Plasma 1,25-dihydroxyvitamin $\mathrm{D}$ levels in primary hyperparathyroidism depend on sex, body mass index, plasma phosphate and renal function. Clin Endocrinol (Oxf). 2007;66(1):35-42. doi:10.1111/ j.1365-2265.2006.02680.x

48. Ludvigsson JF, Kämpe O, Lebwohl B, Green PH, Silverberg SJ, Ekbom A. Primary hyperparathyroidism and celiac disease: a population-based cohort study. J Clin Endocrinol Metab. 2012;97 (3):897-904. doi:10.1210/jc.2011-2639

49. Hu H, Zhang J, Lu Y, et al. Association between circulating vitamin D level and urolithiasis: a systematic review and meta-analysis. Nutrients. 2017;9(3):301. doi:10.3390/nu9030301

50. Ciacci C, Spagnuolo G, Tortora R, et al. Urinary stone disease in adults with celiac disease: prevalence, incidence and urinary determinants. $J$ Urol. 2008;180(3):974-979. doi:10.1016/j. juro.2008.05.007

51. Barnett C, Krebs JE. WSTF does it all: a multifunctional protein in transcription, repair, and replication. Biochem Cell Biol. 2011;89 (1):12-23. doi:10.1139/O10-114

52. Adams JS, Singer FR, Gacad MA, et al. Isolation and structural identification of 1,25-dihydroxyvitamin D3 produced by cultured alveolar macrophages in sarcoidosis. J Clin Endocrinol Metab. 1985;60(5):960-966. doi:10.1210/jcem-60-5-960

53. Cadranel J, Garabedian M, Milleron B, Guillozo H, Akoun G, Hance AJ. 1,25(OH)2D2 production by T lymphocytes and alveolar macrophages recovered by lavage from normocalcemic patients with tuberculosis. J Clin Invest. 1990;85(5):1588-1593. doi:10.1172/JCI114609

54. Hewison M, Kantorovich V, Liker HR, et al. Vitamin D-mediated hypercalcemia in lymphoma: evidence for hormone production by tumor-adjacent macrophages. $J$ Bone Miner Res. 2003;18 (3):579-582. doi:10.1359/jbmr.2003.18.3.579

55. Brenza HL, Kimmel-Jehan C, Jehan F, et al. Parathyroid hormone activation of the 25-hydroxyvitamin D3-1alpha-hydroxylase gene promoter. Proc Natl Acad Sci USA. 1998;95(4):1387-1391. doi:10.1073/pnas.95.4.1387

56. Thompson NW, Eckhauser FE, Harness JK. The anatomy of primary hyperparathyroidism. Surgery. 1982;92(5):814-821.

57. Landin-Wilhelmsen K, Bryman I, Windh M, Wilhelmsen L. Osteoporosis and fractures in Turner syndrome-importance of growth promoting and oestrogen therapy. Clin Endocrinol (Oxf). 1999;51(4):497-502. doi:10.1046/j.1365-2265.1999.00841.x

58. Gonzalez L, Witchel SF. The patient with Turner syndrome: puberty and medical management concerns. Fertil Steril. 2012;98 (4):780-786. https://dx.doi.org/10.1016\%2Fj.fertnstert.2012.07. 1104

59. Wosnitzer MS, Paduch DA. Endocrinological issues and hormonal manipulation in children and men with Klinefelter syndrome. $\mathrm{Am}$ J Med Genet C Semin Med Genet. 2013;163C(1):16-26. doi:10.1002/ajmg.c.31350

60. Hagenfeldt Y, Linde K, Sjöberg HE, Zumkeller W, Arver S. Testosterone increases serum 1,25-dihydroxyvitamin $\mathrm{D}$ and insulin-like growth factor-I in hypogonadal men. Int $J$ Androl. 1992;15(2):93-102. doi:10.1111/j.1365-2605.1992.tb01118.x

61. Rutherford RM, Brutsche MH, Kearns M, Bourke M, Stevens F, Gilmartin JJ. Prevalence of coeliac disease in patients with sarcoidosis. Eur J Gastroenterol Hepatol. 2004;16(9):911-915. doi:10.1097/00042737-200409000-00016

62. Brassard M, AinMelk Y, Baillargeon JP. Basic infertility including polycystic ovary syndrome. Med Clin North Am. 2008;92 (5):1163-1192. doi:10.1016/j.mcna.2008.04.008

63. Baughman RP, Teirstein AS, Judson MA, Rossman MD, Yeager H Jr. Clinical characteristics of patients in a case control study of sarcoidosis. Am J Respir Crit Care Med. 2001;164(10 Pt 1):1885-1889. doi:10.1164/ajrccm.164.10.2104046
64. Heath H 3rd, Hodgson SF, Kennedy MA. Primary hyperparathyroidism. Incidence, morbidity, and potential economic impact in a community. N Engl J Med. 1980;302(4):189-193. doi:10.1056/ NEJM198001243020402

65. Vynnycky E, Fine PE. The natural history of tuberculosis: the implications of age-dependent risks of disease and the role of reinfection. Epidemiol Infect. 1997;119(2):183-201. doi:10.1017/ s0950268897007917

66. Devesa SS, Fears T. Non-Hodgkin's lymphoma time trends: United States and international data. Cancer Res. 1992;52(19 Suppl): 5432s-5440s.

67. Ghaly S, Kaakoush NO, Lloyd F, et al. High dose vitamin D supplementation alters faecal microbiome and predisposes mice to more severe colitis. Sci Rep. 2018;8(1):11511. doi:10.1038/ s41598-018-29759-y

68. Williams JJ, Kaplan GG, Makhija S, et al. Microscopic colitis-defining incidence rates and risk factors: a population-based study. Clin Gastroenterol Hepatol. 2008;6(1):35-40. doi:10.1016/j.cgh.2007. 10.031

69. Olivares M, Walker AW, Capilla A, et al. Gut microbiota trajectory in early life may predict development of celiac disease. Microbiome. 2018;6(1):36. doi:10.1186/s40168-018-0415-6

70. Chavhan SG, Brar RS, Banga HS, et al. Clinicopathological studies on vitamin $\mathrm{D}(3)$ toxicity and therapeutic evaluation of aloe vera in rats. Toxicol Int. 2011;18(1):35-43. doi:10.4103/ 0971-6580.75851

71. Marsh MN, Johnson MW, Rostami K. Mucosal histopathology in celiac disease: a rebuttal of Oberhuber's sub-division of Marsh III. Gastroenterol Hepatol Bed Bench. 2015;8(2):99-109.

72. Yang J, Tamura RN, Aronsson CA, et al. Maternal use of dietary supplements during pregnancy is not associated with coeliac disease in the offspring: The Environmental Determinants of Diabetes in the Young (TEDDY) study. Br J Nutr. 2017;117(3):466-472. doi:10.1017/S0007114517000332

73. Mårild K, Tapia G, Haugen $\mathrm{M}$, et al. Maternal and neonatal vitamin D status, genotype and childhood celiac disease. PLoS One. 2017;12(7):e0179080. doi:10.1371/journal.pone.0179080

74. Yu SM, Kogan MD, Gergen P. Vitamin-mineral supplement use among preschool children in the United States. Pediatrics. 1997;100(5):E4. doi:10.1542/peds.100.5.e4

75. Fogelholm M. New nordic nutrition recommendations are here. Food Nutr Res. 2013;57. doi:10.3402/fnr.v57i0.22903

76. Spiro A, Buttriss JL, Vitamin D. An overview of vitamin D status and intake in Europe. Nutr Bull. 2014;39(4):322-350. https://dx.doi.org/10. $1111 \% 2$ Fnbu. 12108

77. Porojnicu AC, Bruland OS, Aksnes L, Grant WB, Moan J. Sun beds and cod liver oil as vitamin D sources. J Photochem Photobiol B. 2008;91(2-3):125-131. doi:10.1016/j.jphotobiol.2008.02.007

78. Brustad M, Braaten T, Lund E. Predictors for cod-liver oil supplement use - the Norwegian Women and Cancer Study. Eur J Clin Nutr. 2004;58(1):128-136. doi:10.1038/sj.ejcn.1601759

79. Andrews KW, Palachuvattil J, Gusev PA, Dang PT, Savarala S, Han F USDA Dietary Supplement Ingredient Database Release 4.0 (DSID-4): children's multivitamin/mineral (MVM) dietary supplement study; 2015. Available from: https://dietarysupple mentdatabase.usda.nih.gov/dsid_database/Res\%20Summ\% 20Child\%20MVM\%2011-1-2018.pdf. Accessed September 24, 2019.

80. Wagner CL, Greer FR. Prevention of rickets and vitamin D deficiency in infants, children, and adolescents. Pediatrics. 2008;122(5):1142-1152. doi:10.1542/peds.2008-1862

81. Centers for Disease Control. National Center for Health Statistics. Data Table of infant weight-for-age charts. Available from: https://www.cdc. gov/growthcharts/html_charts/wtageinf.htm. Accessed September 24, 2019. 
82. Hypponen E, Sovio $U$, Wjst $M$, et al. Infant vitamin D supplementation and allergic conditions in adulthood: Northern Finland birth cohort 1966. Ann N Y Acad Sci. 2004;1037:84-95. doi:10.1196/annals. 1337.013

83. Milner JD, Stein DM, McCarter R, Moon RY. Early infant multivitamin supplementation is associated with increased risk for food allergy and asthma. Pediatrics. 2004;114(1):27-32. doi:10.1542/peds.114.1.27

84. Back O, Blomquist HK, Hernell O, Stenberg B. Does vitamin D intake during infancy promote the development of atopic allergy? Acta Derm Venereol. 2009;89(1):28-32. doi:10.2340/00015555-0541

85. Nja F, Nystad W, Lodrup Carlsen KC, Hetlevik O, Carlsen KH. Effects of early intake of fruit or vegetables in relation to later asthma and allergic sensitization in school-age children. Acta Paediatr. 2005;94 (2):147-154. doi:10.1111/j.1651-2227.2005.tb01882.x

86. Ress K, Annus T, Putnik U, Luts K, Uibo R, Uibo O. Celiac disease in children with atopic dermatitis. Pediatr Dermatol. 2014;31 (4):483-488. doi:10.1111/pde. 12372

87. Ludvigsson JF, Hemminki K, Wahlstrom J, Almqvist C. Celiac disease confers a 1.6-fold increased risk of asthma: a nationwide population-based cohort study. J Allergy Clin Immunol. 2011;127 (4):1071-1073. doi:10.1016/j.jaci.2010.12.1076

88. Lehtonen-Veromaa MK, Mottonen TT, Nuotio IO, Irjala KM, Leino AE, Viikari JS. Vitamin D and attainment of peak bone mass among peripubertal Finnish girls: a 3-y prospective study. Am J Clin Nutr. 2002;76:1446-1453. doi:10.1093/ajcn/ 76.6.1446

89. Wamberg L, Pedersen SB, Richelsen B, Rejnmark L. The effect of high-dose vitamin D supplementation on calciotropic hormones and bone mineral density in obese subjects with low levels of circulating 25-hydroxyvitamin D: results from a randomized controlled study. Calcif Tissue Int. 2013;93(1):69-77. doi:10.1007/s00223-013-9729-3

90. von Restorff C, Bischoff-Ferrari HA, Theiler R. High-dose oral vitamin D3 supplementation in rheumatology patients with severe vitamin D3 deficiency. Bone. 2009;45(4):747-749. doi:10.1016/j. bone.2009.06.012

91. von Hurst PR, Stonehouse W, Coad J. Vitamin D supplementation reduces insulin resistance in South Asian women living in New Zealand who are insulin resistant and vitamin D deficient a randomised, placebo-controlled trial. Br J Nutr. 2010;103 (4):549-555. doi:10.1017/S0007114509992017

92. Crew KD, Xiao T, Thomas PS, et al. Safety, feasibility, and biomarker effects of high-dose vitamin D supplementation among women at high risk for breast cancer. IJFS. 2015;S1:1-16. doi:10.19070/2326-3350-SI01001

93. Kivelä L, Kaukinen K, Lähdeaho ML, et al. Presentation of celiac disease in finnish children is no longer changing: a 50-year perspective. $J$ Pediatr. 2015;167(5):1109-15.e1. doi:10.1016/j. jpeds.2015.07.057

94. Szymczak I, Pawliczak R. The active metabolite of vitamin D3 as a potential immunomodulator. Scand J Immunol. 2016;83 (2):83-91. doi:10.1111/sji.12403

95. Matheu V, Bäck O, Mondoc E, Issazadeh-Navikas S. Dual effects of vitamin D-induced alteration of $\mathrm{TH} 1 / \mathrm{TH} 2$ cytokine expression: enhancing $\operatorname{IgE}$ production and decreasing airway eosinophilia in murine allergic airway disease. J Allergy Clin Immunol. 2003;112 (3):585-592. doi:10.1016/S0091-6749(03)01855-4

96. Konowalchuk JD, Rieger AM, Kiemele MD, Ayres DC, Barreda DR. Modulation of weanling pig cellular immunity in response to diet supplementation with 25-hydroxyvitamin $\mathrm{D}(3)$. Vet Immunol Immunopathol. 2013;155(1-2):57-66. doi:10.1016/j. vetimm.2013.06.002

97. Nouari W, Ysmail-Dahlouk L, Aribi M. Vitamin D3 enhances bactericidal activity of macrophage against Pseudomonas aeruginosa. Int Immunopharmacol. 2016;30:94-101. doi:10.1016/ j.intimp.2015.11.033
98. Cervantes JL, Oak E, Garcia J, et al. Vitamin D modulates human macrophage response to Mycobacterium tuberculosis DNA. Tuberculosis (Edinb). 2019:S1472-9792(19)30160-X. doi:10.1016/ j.tube.2019.04.021

99. Leonard MM, Bai Y, Serena G, et al. RNA sequencing of intestinal mucosa reveals novel pathways functionally linked to celiac disease pathogenesis. PLoS One. 2019;14(4):e0215132. doi:10.1371/journal.pone. 0215132

100. Calton EK, Keane KN, Newsholme P, Soares MJ. The impact of vitamin D levels on inflammatory status: a systematic review of immune cell studies. PLoS One. 2015;10(11):e0141770. doi:10.1371/journal.pone.0141770

101. Harishankar M, Afsal K, Banurekha VV, Meenakshi N, Selvaraj P. 1,25-Dihydroxy vitamin D3 downregulates pro-inflammatory cytokine response in pulmonary tuberculosis. Int Immunopharmacol. 2014;23(1):148-152. doi:10.1016/j.intimp.2014.08.021

102. Barker T, Martins TB, Hill HR, et al. Circulating pro-inflammatory cytokines are elevated and peak power output correlates with 25-hydroxyvitamin D in vitamin D insufficient adults. Eur J Appl Physiol. 2013;113(6):1523-1534. doi:10.1007/s00421-012-2582-7

103. Del Pinto R, Pietropaoli D, Chandar AK, Ferri C, Cominelli F. Association between inflammatory bowel disease and vitamin D deficiency: a systematic review and meta-analysis. Inflamm Bowel Dis. 2015;21(11):2708-2717. doi:10.1097/MIB.0000000000000546

104. Mousa A, Naderpoor N, Johnson J, et al. Effect of vitamin D supplementation on inflammation and nuclear factor kappa-B activity in overweight/obese adults: a randomized placebo-controlled trial. Sci Rep. 2017;7(1):15154. doi:10.1038/ s41598-017-15264-1

105. Hopkins $\mathrm{MH}$, Owen J, Ahearn T, et al. Effects of supplemental vitamin $\mathrm{D}$ and calcium on biomarkers of inflammation in colorectal adenoma patients: a randomized, controlled clinical trial. Cancer Prev Res (Phila). 2011;4(10):1645-1654. doi:10.1158/1940-6207. CAPR-11-0105

106. Jackson RD, LaCroix AZ, Gass $\mathrm{M}$, et al. Calcium plus vitamin D supplementation and the risk of fractures. $N$ Engl J Med. 2006;354(7):669-683. https://doi.org/10.1056/NEJMoa055218

107. Protiva P, Pendyala S, Nelson C, Augenlicht LH, Lipkin M, Holt PR. Calcium and 1,25-dihydroxyvitamin D3 modulate genes of immune and inflammatory pathways in the human colon: a human crossover trial. Am J Clin Nutr. 2016;103(5):1224-1231. doi:10.3945/ajen.114.105304

108. Bragde H, Jansson U, Fredrikson M, Grodzinsky E, Söderman J Celiac disease biomarkers identified by transcriptome analysis of small intestinal biopsies. Cell Mol Life Sci. 2018;75 (23):4385-4401. doi:10.1007/s00018-018-2898-5

109. Hornsby E, Pfeffer PE, Laranjo N, et al. Vitamin D supplementation during pregnancy: effect on the neonatal immune system in a randomized controlled trial. J Allergy Clin Immunol. 2018;141 (1):269-278.e1. doi:10.1016/j.jaci.2017.02.039

110. Szebeni B, Veres G, Dezsofi A, et al. Increased mucosal expression of Toll-like receptor (TLR)2 and TLR4 in coeliac disease. J Pediatr Gastroenterol Nutr. 2007;45(2):187-193. doi:10.1097/MPG.0b01 3e318064514a

111. Monteleone I, Sarra M, Del Vecchio Blanco G, et al. Characterization of IL-17A-producing cells in celiac disease mucosa. J Immunol. 2010;184 (4):2211-2218. doi:10.4049/jimmunol.0901919

112. Akhtar E, Mily A, Haq A, et al. Prenatal high-dose vitamin D3 supplementation has balanced effects on cord blood Th1 and Th2 responses. Nutr J. 2016;15(1):75. doi:10.1186/s12937-0160194-5

113. Goncalves-Mendes N, Talvas J, Dualé C, et al. Impact of vitamin D supplementation on influenza vaccine response and immune functions in deficient elderly persons: a randomized placebo-controlled trial. Front Immunol. 2019;10:65. doi:10.3389/fimmu.2019.00065 
114. Lionetti P, Pazzaglia A, Moriondo M, et al. Differing patterns of transforming growth factor-beta expression in normal intestinal mucosa and in active celiac disease. $J$ Pediatr Gastroenterol Nutr. 1999;29(3):308-313. doi:10.1097/ 00005176-199909000-00013

115. Bak NF, Bendix M, Hald S, Reinert L, Magnusson MK, Agnholt J. High-dose vitamin D3 supplementation decreases the number of colonic CD103+ dendritic cells in healthy subjects. Eur $J$ Nutr. 2018;57(7):2607-2619. doi:10.1007/s00394-017-1531-y

116. Myleus A. Towards Explaining the Swedish Epidemic of Celiac Disease - An Epidemiological Approach. Umeå, Sweden: Department of Public Health and Clinical Medicine, Epidemiology and Global Health; 2012.

117. Livsmedelsverket. Livsmedelsverkets Föreskrifter (SLVFS 1983:2) om Berikning av Vissa Livsmedel (Food agency's order about fortification of foodstuffs). Available from: https://www.livsmedels verket.se/globalassets/om-oss/lagstiftning/berikn—;kosttillsklivsm-spec-gr-fsmp/slvfs-1983-02-kons.pdf. Accessed September 24, 2019.

118. Lamberg-Allardt C, Ala-Houhala M, Ahola M, Parviainen MT, Räsänen L, Visakorpi J. Vitamin D status of children and adolescents in Finland. Ann Nutr Metab. 1986;30(4):267-272. doi:10.1159/000177203

119. Klaukka T, Riska E, Kimmel UM. Use of vitamin supplements in Finland. Eur J Clin Pharmacol. 1985;29(3):355-361. doi:10.1007/ bf00544094

120. Lamberg-Allardt CJ, Outila TA, Kärkkainen MU, Rita HJ, Valsta LM. Vitamin D deficiency and bone health in healthy adults in Finland: could this be a concern in other parts of Europe? J Bone Miner Res. 2001;16 (11):2066-2073. doi:10.1359/jbmr.2001.16.11.2066

121. Kratzer W, Kibele M, Akinli A, et al. Prevalence of celiac disease in Germany: a prospective follow-up study. World J Gastroenterol. 2013;19(17):2612-2620. doi:10.3748/wjg.v19.i17.2612

122. Hakala P, Knuts LR, Vuorinen A, Hammar N, Becker W. Comparison of nutrient intake data calculated on the basis of two different databases. Results and experiences from a Swedish-Finnish study. Eur J Clin Nutr. 2003;57(9):1035-1044. doi:10.1038/sj.ejcn.1601639

123. Hintzpeter B, Mensink GB, Thierfelder W, Müller MJ, Scheidt-Nave C. Vitamin D status and health correlates among German adults. Eur J Clin Nutr. 2008;62(9):1079-1089. doi:10.1038/sj.ejen.1602825

124. Catassi C, Kryszak D, Bhatti B, et al. Natural history of celiac disease autoimmunity in a USA cohort followed since 1974. Ann Med. 2010;42(7):530-538. doi:10.3109/07853890.2010.514285

125. Picciano MF, Dwyer JT, Radimer KL, et al. Dietary supplement use among infants, children, and adolescents in the United States, 1999-2002. Arch Pediatr Adolesc Med. 2007;161(10):978-985. doi:10.1001/archpedi.161.10.978

126. Kantor ED, Rehm CD, Du M, White E, Giovannucci EL. Trends in dietary supplement use among US adults from 1999-2012. JAMA. 2016;316(14):1464-1474. doi:10.1001/jama.2016.14403

127. Rooney MR, Harnack L, Michos ED, Ogilvie RP, Sempos CT, Lutsey PL. Trends in use of high-dose vitamin D supplements exceeding 1000 or 4000 international units daily, 1999-2014. JAMA. 2017;317(23):2448-2450. doi:10.1001/jama.2017.4392

128. Institute of Medicine (US) Committee on Use of Dietary Reference Intakes in Nutrition Labeling. Dietary Reference Intakes: Guiding Principles for Nutrition Labeling and Fortification. Washington, DC: National Academies Press (US); 2003.

129. Landren WO Jr, Eitenmueller RR, Soliman AM. Vitamin D3 and vitamin K1 levels in infant formula produced in the United States. J Food Compos Anal. 1989;2(2):140-148. doi:10.1016/0889-1575(89) 90074-4

130. Murphy SC, Newcomer C. Guideline for Vitamin $A$ \& $D$ Fortification of Fluid Milk. New Jersey: The Dairy Practices Council; 2001.
131. Cataldo F, Lio D, Simpore J, Musumeci S. Consumption of wheat foodstuffs not a risk for celiac disease occurrence in burkina faso. J Pediatr Gastroenterol Nutr. 2002;35(2):233-234. doi:10.1097/ 00005176-200208000-00029

132. USAID. Burkina Faso: nutrition profile; 2018. Available from: https://www.usaid.gov/sites/default/files/documents/1864/BurkinaFaso-Nutrition-Profile-Mar2018-508.pdf. Accessed September 24, 2019.

133. Addo D, Yadav V, Njiru H, et al. Government leadership needed for food fortification in sub saharan Africa. Am J Public Health. 2010;100(12):2333-2334. doi:10.2105/AJPH.2010.206896

134. Kondrashova A, Mustalahti K, Kaukinen K, et al. Lower economic status and inferior hygienic environment may protect against celiac disease. Ann Med. 2008;40(3):223-231. doi:10.1080/0785389070 1678689

135. Tylavsky FA, Cheng S, Lyytikäinen A, Viljakainen H, LambergAllardt C. Strategies to improve vitamin D status in northern European children: exploring the merits of vitamin D fortification and supplementation. J Nutr. 2006;136(4):1130-1134. doi:10.1093/ $\mathrm{jn} / 136.4 .1130$

136. Kodentsova VM, Vrzhesinskaia OA, Sokol'nikov AA. Food fortified with vitamins: the history and perspectives. Vopr Pitan. 2012;81:66-78.

137. Bakhtiyarova S, Lesnyak O, Kyznesova N, Blankenstein MA, Lips P. Vitamin D status among patients with hip fracture and elderly control subjects in Yekaterinburg, Russia. Osteoporos Int. 2006;17:441-446. doi:10.1007/s00198-005-0006-9

138. Akobeng AK, Ramanan AV, Buchan I, Heller RF. Effect of breast feeding on risk of coeliac disease: a systematic review and meta-analysis of observational studies. Arch Dis Child. 2006;91 (1):39-43. doi:10.1136/adc.2005.082016

139. Silano M, Agostoni C, Sanz Y, Guandalini S. Infant feeding and risk of developing celiac disease: a systematic review. BMJ Open. 2016;6(1):e009163. doi:10.1136/bmjopen-2015-009163

140. Arundel P, Ahmed SF, Allgrove J, et al. British Paediatric and Adolescent Bone Group's position statement on vitamin D deficiency. BMJ. 2012;345:e8182. doi:10.1136/bmj.e8182

141. Smecuol E, Mauriño E, Vazquez $\mathrm{H}$, et al. Gynaecological and obstetric disorders in coeliac disease: frequent clinical onset during pregnancy or the puerperium. Eur J Gastroenterol Hepatol. 1996;8 (1):63-89. doi:10.1097/00042737-199601000-00012

142. Corrado F, Magazzu G, Sferlazzas C. Diagnosis of celiac disease in pregnancy and puerperium: think about it. Acta Obstet Gynecol Scand. 2002;81(2):180-181. doi:10.1034/j.1600-0412.2002.810219.x

143. Kumar R, Cohen WR, Silva P, Epstein FH. Elevated 1,25-dihydroxyvitamin D plasma levels in normal human pregnancy and lactation. $J$ Clin Invest. 1979;63(2):342-344. doi:10.1172/ JCI109308

144. Narang M, Puri AS, Sachdeva S, Singh J, Kumar A, Saran RK. Celiac disease and Helicobacter pylori infection in children: is there any Association? J Gastroenterol Hepatol. 2017;32(6):1178-1182. doi:10.1111/jgh.13654

145. Hu W, Zhang L, Li MX, et al. Vitamin D3 activates the autolysosomal degradation function against Helicobacter pylori through the PDIA3 receptor in gastric epithelial cells. Autophagy. 2019;15 (4):707-725. doi:10.1080/15548627.2018.1557835

146. Brar P, Lee AR, Lewis SK, Bhagat G, Green PH. Celiac disease in African-Americans. Dig Dis Sci. 2006;51(5):1012-1015. doi:10.1007/s10620-005-9000-5

147. Mardini HE, Westgate P, Grigorian AY. Racial differences in the prevalence of celiac disease in the US Population: National Health and Nutrition Examination Survey (NHANES) 2009-2012. Dig Dis Sci. 2015;60(6):1738-1742. doi:10.1007/ s10620-014-3514-7 
148. Balluz LS, Kieszak SM, Philen RM, Mulinare J. Vitamin and mineral supplement use in the United States. Results from the third National Health and Nutrition Examination Survey. Arch Fam Med. 2000;9(3):258-262. doi:10.1001/archfami.9.3.258

149. Vazquez H, Smecuol E, Flores D, et al. Relation between cigarette smoking and celiac disease: evidence from a case-control study. Am J Gastroenterol. 2001;96(3):798-802.

150. Hoggatt KJ, Bernstein L, Reynolds P, et al. Correlates of vitamin supplement use in the United States: data from the California Teachers Study cohort. Cancer Causes Control. 2002;13 (8):735-740. doi:10.1023/A:1020282927074

151. Brot C, Jorgensen NR, Sorensen OH. The influence of smoking on vitamin D status and calcium metabolism. Eur J Clin Nutr. 1999;53 (12):920-926. doi:10.1038/sj.ejcn.1600870

152. Whyte LA, Kotecha S, Watkins WJ, Jenkins HR. Coeliac disease is more common in children with high socio-economic status. Acta Paediatr. 2014;103(3):289-294. doi:10.1111/apa.12494

153. Canova C, Zabeo V, Pitter G, et al. Association of maternal education, early infections, and antibiotic use with celiac disease: a population-based birth cohort study in northeastern Italy. Am $J$ Epidemiol. 2014;180(1):76-85. doi:10.1093/aje/kwu101

154. Dickinson A, MacKay D. Health habits and other characteristics of dietary supplement users: a review. Nutr J. 2014;13:14. doi:10.1186/1475-2891-13-14

155. Okada H, Kuhn C, Feillet H, Bach JF. The 'hygiene hypothesis' for autoimmune and allergic diseases: an update. Clin Exp Immunol. 2010;160(1):1-9. https://doi.org/10.1111/j.1365-2249. 2010.04139.x

156. Esrey SA, Potash JB, Roberts L, Shiff C. Effects of improved water supply and sanitation on ascariasis, diarrhoea, dracunculiasis, hookworm infection, schistosomiasis, and trachoma. Bull World Health Organ. 1991;69(5):609-621.

157. Goodsell W. Housing and the birth rate in Sweden. Am Sociol Rev. 1937;2(6):850-859. doi:10.2307/2084364
158. Strom J. The Fall of Infant Mortality in Sweden and its Causes. Nord Med. 1953;50(38):1285-1294.

159. OECD. Per country data on health; 2018. Available from: https:// www.oecd.org/. Accessed September 24, 2019

160. Samsel A, Seneff S. Glyphosate, pathways to modern diseases II: celiac sprue and gluten intolerance. Interdiscip Toxicol. 2013;6 (4):159-184. doi:10.2478/intox-2013-0026

161. Schweinsberg F, Abke W, Rieth K, Rohmann U, Zullei-Seibert N. Herbicide use on railway tracks for safety reasons in Germany. Toxicol Lett. 1999;107(1-3):201-205. doi:10.1016/S0378-4274(99) 00048-X

162. Skark C, Zullei-seibert N, Schottler U, Schlett C. The occurrence of glyphosate in surface water. Int J Environ Anal Chem. 1998;70 (1-4):93-104. doi:10.1080/03067319808032607

163. Steinmann HH, Dickeduisberg M, Theuvsen L. Uses and benefits of glyphosate in German arable farming. Crop Protection. 2012;42:164-169. doi:10.1016/j.cropro.2012.06.015

164. Horth H, Blackmore K. Survey of glyphosate and AMPA in groundwaters and surface waters in Europe. Monsanto; 2009. Available from: http://www.egeis.org/cd-info/WRC-report-UC8073-02-December -2009-Glyphosate-monitoring-in-water.pdf. Accessed September 24, 2019.

165. Lerner A, Matthias T. Possible association between celiac disease and bacterial transglutaminase in food processing: a hypothesis. Nutr Rev. 2015;73(8):544-552. doi:10.1093/nutrit/nuv011

166. Ando $\mathrm{H}$, Adachi $\mathrm{M}$, Umeda $\mathrm{K}$, Matsuura A, Nonaka M. Purification and characteristics of a novel transglutaminase derived from microorganisms. Agr Bio Chem. 1989;53(10):2613-2617. doi:10.1080/00021369.1989.10869735

167. Kieliszek M, Misiewicz A. Microbial transglutaminase and its application in the food industry. A review. Folia Microbiol (Praha). 2014;59(3):241-250. doi:10.1007/s12223-013-0287-x
Clinical and Experimental Gastroenterology

\section{Publish your work in this journal}

Clinical and Experimental Gastroenterology is an international, peerreviewed, open access, online journal publishing original research, reports, editorials, reviews and commentaries on all aspects of gastroenterology in the clinic and laboratory. This journal is indexed on American Chemical Society's Chemical Abstracts Service (CAS)
The manuscript management system is completely online and includes a very quick and fair peer-review system, which is all easy to use. Visit http://www.dovepress.com/testimonials.php to read real quotes from published authors. 